\title{
Reflections on the Jesuit Mission to China
}

\section{Citation}

Winston, Kenneth, and Mary Jo Bane. 2010. Reflections on the Jesuit Mission to China. HKS Faculty Research Working Paper Series, RWP10-004, John F. Kennedy School of Government, Harvard University.

\section{Published Version}

http://web.hks.harvard.edu/publications/workingpapers/citation.aspx?Publd=7095

\section{Permanent link}

http://nrs.harvard.edu/urn-3:HUL.InstRepos:4454153

\section{Terms of Use}

This article was downloaded from Harvard University's DASH repository, and is made available under the terms and conditions applicable to Other Posted Material, as set forth at http:// nrs.harvard.edu/urn-3:HUL.InstRepos:dash.current.terms-of-use\#LAA

\section{Share Your Story}

The Harvard community has made this article openly available.

Please share how this access benefits you. Submit a story.

Accessibility 


\title{
Reflections on the Jesuit Mission to China Faculty Research Working Paper Series
}

\author{
Kenneth Winston
}

Harvard Kennedy School

\section{Mary Jo Bane}

Harvard Kennedy School

\section{February 2010 RWP10-004}

The views expressed in the HKS Faculty Research Working Paper Series are those of the author(s) and do not necessarily reflect those of the John F. Kennedy School of Government or of Harvard University. Faculty Research Working Papers have not undergone formal review and approval. Such papers are included in this series to elicit feedback and to encourage debate on important public policy challenges. Copyright belongs to the author(s). Papers may be downloaded for personal use only. 


\section{Working Paper}

February 1, 2010

\section{Reflections on the Jesuit Mission to China}

Kenneth Winston and Mary Jo Bane

Harvard Kennedy School

In 2006, we had the privilege of visiting the gravesites in the Zhalan cemetery, located outside the old city gate in Beijing, of Matteo Ricci and his Jesuit colleagues, Johann Adam Schall and Ferdinand Verbiest. These sites were restored after the Cultural Revolution and commemorated on the $400^{\text {th }}$ anniversary of Ricci's arrival in China, in 1983 . The memory of the Jesuit mission to China is now carefully preserved, for it was the Jesuits who were largely responsible for opening up China to Europe in the modern period. This early encounter between East and West endures in significance. ${ }^{1}$

A constant theme in such East-West encounters, over the centuries, is the endeavor of the western visitors “to change China,” in Jonathan Spence’s felicitous phrase. These efforts failed for the most part, for the Chinese proved to be exceedingly adept at turning the barbarians against themselves and protecting what they most valued in their culture and way of life. Yet, the story of the various attempts to bring about change "speak[s] to us still ... about the ambiguities of superiority, and about that indefinable realm where altruism and exploitation meet."2

This story has a special salience in our own time. With the explosive growth of transnational dealings, professionals in developed countries, especially the United States, have expanding opportunities to spread their particular ways of doing things around the world. And many of our compatriots, we know, are eager to take advantage of these opportunities, for in the

\footnotetext{
${ }^{1}$ The Zhalan cemetery is in a lovely park on the grounds of Beijing Party School. Our host in 2006 was the bureau head of the Office for Letters and Visits from the Masses for the Beijing municipality. For a history of the cemetery, with descriptions of the 63 tombstones on the site, see Edward J. Malatesta, SJ, and Gao Zhiyu, Departed, Yet Present: Zhalan, The Oldest Christian Cemetery in Beijing (San Francisco: Ricci Institute, University of San Francisco, 1995).

2 Jonathan D. Spence, To Change China: Western Advisers in China (New York: Penguin Books, 1980 [original 1969]), introduction (unpaginated).
} 
U.S., as our Harvard colleague William Alford observes, we have a long history "of endeavoring to enlighten, if not save, our foreign brethren by exporting ideas and institutions that we believe we have realized more fully." ${ }^{3}$ Indeed, our principal reason for being in Beijing in 2006 was to participate as faculty members in a training program for Chinese government officials. Engaged in our own form of missionary work, we presented ourselves as experts in "best practices" (regarding ethics and social policy) and attempted to demonstrate their attractiveness.

Missionary work, however, raises fundamental questions. Under what conditions, if any, should professionals of one country be seeking to promote in another their own values and commitments? Are we correct to assume that our standards of good professional conduct have universal applicability? Does missionary work reflect a failure to appreciate alternative modes of human flourishing? Whether the export of values results from genuinely cooperative endeavors or from taking advantage of vulnerable populations, professionals are obligated, we believe, to confront the far-reaching effects of their efforts and assess the standards by which they operate.

To examine these questions, we decided to explore the work of the figures whose gravesites we observed at the Zhalan cemetery. It is estimated that more than 900 Jesuits worked in China from 1583 until they were expelled in the mid-18 ${ }^{\text {th }}$ century. Our focus is specifically on the initial period and especially the most well known of the Jesuit visitors, Matteo Ricci, who set the pattern for the Jesuit mission in China for many decades (with occasional reference to his most prominent followers, Schall and Verbiest). These professional missionaries worked unabashedly to export the values of the Christian gospel and Catholic practices. In so doing, they also exported western knowledge, skills, and ways of doing things in other domains.

What follows, then, is a set of reflections based on our reading and our conversations with each other. We are not historians or China experts. Our interest is in what we call "the ethics of missionary work,” for which the Jesuit adventure in China provides an especially intriguing example to learn from. Ken is listed as principal author because this account fits into a larger project he is undertaking on exporting ethics; Mary Jo’s principal concern is to reconcile her commitment to "taking faith seriously" (the title of a recent collection of essays she edited)

\footnotetext{
${ }^{3}$ William P. Alford, “Exporting ‘The Pursuit of Happiness,’” Harvard Law Review 113:7 (2000), 1678.
} 
with respect for cultural, including religious, diversity. These reflections are steps on the way to these larger endeavors.

\section{The Society of Jesus and Early Modern Catholicism.}

We begin with a very brief sketch of the political and cultural context of the Jesuit mission. As the story unfolds, we identify a variety of sources that readers may wish to consult if they are interested in more in-depth accounts. Our aim is simply to set the scene for our reflections.

The Society of Jesus was founded by Ignatius of Loyola and ten companions in 1534 and received papal approval in $1540 .{ }^{4}$ The purpose of the Society was, in its own words, the defense and propagation of the faith and the progress of souls in Christian life and doctrine.

Characterized sometimes as less a monastic order than a well-trained religious militia, it differed from existing religious orders in important ways. While members took the customary religious vows of poverty, chastity and obedience, they also made a special commitment to undertaking ministry anywhere in the world. Their thought was that the spiritual message of Jesus was not bound by geography or culture but intended for all. Thus, teaching and spreading the gospel across the globe became a principal focus. (From early in their history, the founding and operation of schools was a central activity.) Jesuits also spent less time in communal prayer than members of most religious orders; they were much more active and itinerant, more flexible about dress and daily routines.

The Jesuits recognized from the beginning the special qualities that set them apart. The deep commitment to mission required not just "great abnegation of self” but "great labors," including such learning that only a select few could qualify for membership. In addition, they were set apart by their religious training. The Spiritual Exercises, developed by Ignatius, constituted the centerpiece of Jesuit spirituality and practice. The Exercises, which every Jesuit went through fully at least once and renewed regularly, were (and still are) an extended program of prayer and contemplation meant to solidify an identification with Jesus and to teach methods of discerning the will of God in the world. With members dispersed over the whole globe and

\footnotetext{
4 Sources for this section include John W. O’Malley, SJ, The First Jesuits (Cambridge: Harvard University Press, 1993); R. Po-Chia Hsia, The World of Catholic Renewal: 1540-1770 (Cambridge, Eng.: Cambridge University Press, 1998); and Andrew Pettigree, Europe in the Sixteenth Century (Malden: Blackwell Publisher, 2002).
} 
living independently, the spirituality and active orientation of the Exercises were key unifying mechanisms, reinforced by the vow of obedience, which Ignatius interpreted as instant and unquestioning deference to the will of superiors. The Exercises and the hierarchical organization sustained the values of the Society and the responsibility of each Jesuit to act individually in the world in response to God's personal call.

The first few decades of the Society were the same years in which the Protestant Reformation was sweeping through Europe, first in Germany, then in Switzerland and England. France was contested territory, with the violent wars of religion ravaging the country during the last half of the sixteenth century. In Spain, Italy, and Portugal, where most of the early Jesuits came from, Catholicism was fiercely defended by the rulers and remained the majority religion. This dominance was accompanied, however, by the state-sanctioned efforts of the Inquisition in rooting out and punishing heresy and suspect practices.

The Catholic response to the Reformation focused on affirmation of the doctrines that distinguished it from Protestantism, combined with reform of its own institutions. The Council of Trent, convened by the Pope in 1545 and continued until 1563, dealt with dogma first, reform second. It reaffirmed the importance of good works in contrast to Luther's notion of justification by faith. It also reaffirmed the authority of the Latin Vulgate translation of the bible, the Latin Mass, clerical celibacy, and the reception of communion in the form only of bread, not of wine. The Council brooked no compromises with the Protestant reformers, even on issues, like Communion, which might easily have been negotiated.

The Jesuits’ mission quickly took them far afield. By 1556, the Society was working in India, Brazil, and Ethiopia, as well as in Portugal, Castile, Aragon, Andalusia, Italy, Sicily, Upper Germany, Lower Germany, and France. Francis Xavier was in Japan in 1540 and preparing to move into China at the time of his death in 1552. In all of this work, the Society was concerned especially to uphold those aspects of the faith under severest attack, including fine points of doctrine and ritual and practices like the granting of indulgences. At the same time, the Jesuit "way of proceeding” was strikingly practical. Ignatius and those who followed him as superiors general foresaw that Jesuits would often find themselves in alien, if not overtly hostile, environments and would need effective strategies for carrying out their work. In pursuit of their mission of teaching, preaching, and "helping souls” (Ignatius' term), they were instructed to be prepared to make accommodations to the situation and needs of the persons to whom they 
ministered; to be responsive to the powers that be; and to modify their way of life, to increase their effectiveness.

Some scholars see the accommodationist strategy as a later development, even an invention of Matteo Ricci responding to the special difficulties in gaining entry to China. However, the seeds of it are evident in several of Ignatius's letters. Among the instructions to German missionaries in 1549 is the admonition: "Make yourselves loved by your humility and charity, becoming all things to all men. Show that you conform, as far as the Institute of the Society permits, to the customs of the people there.” (213) ${ }^{5}$ In a 1555 letter to the newly appointed patriarch of Ethiopia, John Nunez Barreto, Ignatius instructs Barreto to be prepared to teach matters of faith and morals "in a way that is accommodated to those people.... Without taking away from [the Ethiopians] anything in which they are particularly interested or which they especially value, try to get them to accept the truths of Catholicism.” (384) Later, he adds: "Although you are ever intent on bringing them to conformity with the Catholic Church, do everything gently, without any violence to souls long accustomed to another way of life.” (387)

As elaborated by Ignatius’ successors, the effort at conforming to people’s customs and ways of understanding became known as inculturation, one of the central components of the accommodationist strategy.

What makes it especially appropriate to regard accommodation as a strategy is that Ignatius's instructions were often prudential. Since missionaries must husband their energies, it is best to deal with persons "from whom we can expect greater fruit," especially "those in high position who exert an influence because of their learning or their possessions.” (268) The more solemn the missionary’s presentation, the more authority it will carry. (382) Official church documents "should be as beautiful to the eye as possible.” (384) Gifts, especially of items esteemed by the potential converts, will help in winning people’s hearts. (382) And it would be a "good idea” for missionaries to bring along "men of practical genius” who can offer instruction on cultivating the land, building bridges, improving health care "so that it may appear ... that [the converts'] total good, even bodily good, is coming to them with their religion.” (388)

\footnotetext{
${ }^{5}$ The quotations in these paragraphs are from Letters of St. Ignatius of Loyola, translated by William J. Young, SJ (Chicago: Loyola University Press, 1959). Page citations are inserted in the text.
} 
As a result, the practice of accommodation, in the words of a leading contemporary Jesuit historian, could "be separated [sometimes] by only a hair's breadth, or less, from opportunism."” That hair's breadth is our central concern as we explore the Jesuits' missionary work in China, for it was in the Chinese mission that the Jesuits "carried their pastoral principle of accommodation ... to its utmost expression." At the close of this essay, we will consider the question whether the accommodationist strategy can be defended in principled terms.

\section{China in Decline and Transition.}

The Jesuits worked in China during the period of the late Ming and early Qing dynasties, a period of political decline, bloody transition, and at the end reasonably competent rule and prosperity. ${ }^{8}$ At the turn of the $17^{\text {th }}$ century, China was a country of an estimated 200 to 230 million people, over a third of the total world population and far larger than all the European countries combined. It was prosperous relative to world standards of the day, with a growing population of overwhelmingly rural villagers. Trade in commodities was becoming increasingly common, with continuing improvements in infrastructure and the emergence of regional and national commercial networks, although much of it was highly regulated by the central government. Long before, China had developed a system of government from the center that more or less kept order and brought unity to the vast expanses of the subcontinent. During the late Ming, the country was poorly governed but not a total disaster. The Wanli emperor, who ruled from 1573 to 1620, was inept and avaricious, sanctioning both high taxation and extortion by provincial officials.

The last of the Ming rulers, the Chongzhen emperor who ruled from 1628 to 1645, was threatened by internal bandit armies and Manchu invaders from the north. In 1644, Beijing fell to the bandit Li Zichang, and the emperor committed suicide. Shortly thereafter, the Manchus succeeded in conquering the country and established a new ruling dynasty, the Qing. The bloody, chaotic transition period came to an end during the time of the Kangxi emperor, who ruled from 1662 to 1722 . He was able to consolidate Manchu rule and extend the territory of

\footnotetext{
${ }^{6}$ O’Malley, 81.

${ }^{7}$ Ibid., 342.

${ }^{8}$ On the history of this period, see especially F. W. Mote, Imperial China: 900-1800 (Cambridge: Harvard University Press, 1999); and Jonathan Spence, The Search for Modern China (New York: W. W. Norton, 1990).
} 
China as far as Taiwan and Tibet. The political stability he managed to achieve, however, was undercut at the end of his reign, when his failure to provide for a successor led to another period of turmoil.

Fairbank and Goldman describe late imperial China as experiencing "growth without development.” ${ }^{9}$ The expanding population put increased pressure on scarce arable land, and expansions of economic output came from increases in labor rather than greater productivity. ${ }^{10}$ The cultivation of rice, the basic staple, was extremely labor intensive. Most non-agricultural production was carried on at home. However, in the period of concern to us here, Chinese peasants do not appear to have been worse off, and may have been better off, than average Europeans. Nor is it clear that the social disintegration of the transition period and the internal violence that continued were any greater than that experienced during the European wars of religion.

A distinctive feature of governance in China was that it was largely in the hands of educated elites. $^{11}$ Beginning in the Han dynasty (206 BCE to $220 \mathrm{CE}$ ) when Confucianism became the official philosophy of the imperial regime, and especially from the time of the Tang dynasty (618 to $907 \mathrm{CE}$ ) when the examination system was consolidated, government ministries were run by literati [wenren], commonly referred to as scholar-officials [shidafu]. These scholar-officials were a self-conscious, educated social group who took it as their highest calling to enter government service, typically in the central bureaucracy or in provincial administrations. As humanists steeped in the moral wisdom of the past (i.e., the classic Confucian texts), they had the duty to protect traditional values in the political realm: to serve as the conscience of rulerscounseling them through moral suasion, remonstrating with them to rectify defective policies, chastising them for personal failings — sometimes at great personal risk. They offered a moral compass, based on learning and reflection, and served as critics, moral educators, and disinterested proponents of the public good. Given the strong grip of Confucianism in the ruling

9 John King Fairbank and Merle Goldman, China: A New History (Cambridge: Harvard University Press, 1998), 167-186.

10 Kenneth Pomeranz, The Great Divergence: China, Europe, and the Making of the Modern World Economy (Princeton: Princeton University Press, 2000).

11 The paragraphs on scholar-officials draw on Kenneth Winston, “Advisors to Rulers: Serving the State and the Way,” in Prospects for Professionalism in China, edited by William P. Alford, William C. Kirby, and Kenneth Winston (Routledge, forthcoming). 
class, these authoritative interpreters of the classic texts were often a potent force in policy making.

Like the Jesuits, scholar-officials met most of the standard criteria of a profession. They constituted a distinct social category, with a collective identity and a shared ethos, including the commitment to protect and promote an important public value. ${ }^{12}$ Their rigorous examination system established them as masters of an intellectual tradition, an esoteric body of knowledge that, in its application, required complex judgment. This body of knowledge defined an educational curriculum (for recruiting and training members of the profession) and standards of "best practice” (for governance itself and hence the advice that rulers should receive). Since knowledge of the classics and literary skills based on them were the criteria of appointment, successful applicants typically lacked practical training and administrative experience. In this respect they were no different, perhaps, from managerial elites in other flourishing preindustrial societies.

Being educated to the responsibilities of office, scholar-officials acted as intermediaries between the rulers and the ruled-guardians of moral standards and arbiters of public affairs, guiding rulers toward a more humane society. (Since the emperor was the link between heaven and earth, the ruler's moral character and actions were critical to the well being of the whole society.) In this way, scholar-officials fulfilled the standard functions of mandarin elites, providing legitimacy to the regime they served while reciprocally setting constraints, or at least articulating standards of constraint, for the exercise of political power. This privileged alliance with rulers - which depended not on caste or inheritance or political constituency but on examinations - gave them an enhanced status, and they were held in high esteem.

Charles Hucker observes that the very existence of the practice of remonstrance was premised on the fallibility - and corrigibility_of the ruler. ${ }^{13}$ Not all rulers accepted the implication. By the time of the Jesuit entry into China, scholar-officials had experienced the intolerance of criticism and indeed notorious cruelties of some of the Ming emperors. As a result, many of them exhibited a good deal of ambivalence toward the enterprise of governance.

\footnotetext{
${ }^{12}$ On the principal features of a profession, see Philip Selznick, Leadership in Administration: A Sociological Interpretation (Berkeley: University of California Press, 1984), 120-123.

${ }^{13}$ Charles Hucker, "Confucianism and the Chinese Censorial System," in Confucianism and Chinese Civilization, edited by Arthur F. Wright (Stanford: Stanford University Press, 1964), 57.
} 
In particular, some believed that participation in governance inevitably imperiled the moral person. In the words of Sung Lien, a high ranking scholar of the early Ming: "Effectiveness demands cooperation with the world, which in turn means loss of self, and loss of self means loss of virtue." 14

This alienation increased as the Ming dynasty endured, and it helped to foster a genre of autobiographical writing in which the classical Confucian sense of reserve and stoic perseverance gave way to harsh self-disclosure and public repentance and concerns about personal spiritual progress. ${ }^{15}$ This development created, or at least exacerbated, the divide between morality and politics. Moral reform came to be regarded as a private affair, a matter of personal self-transformation, an effort to achieve moral perfection in one's own life, exemplified in techniques of self-vigilance and moral bookkeeping such as ledgers of merits and demerits. This was fertile ground, in Wu's words, for a "burning urgency in the search for ultimate truth" and consideration of novel forms of spiritual perfection, which came to an end only when the Qing dynasty consolidated its rule and, by a series of edicts over several decades, imposed a new Confucian orthodoxy. ${ }^{16}$

Adding to this shift of values was the fact that, during the Ming dynasty, the examination system became increasingly hide-bound, relying on rote memorization and requiring mastery of arcane literary forms, for example. As a result, many highly qualified aspirants for office failed the examinations repeatedly or refused to sit for them at all. While Confucians had reason to preserve palace examinations as a check on the influence of other groups, especially the eunuchs in the imperial court, they felt the system had somehow gone awry. At the same time, the Confucian worldview itself was indomitable: "Perhaps in no other society of comparable complexity and development (level of literacy, rate of urbanization, scale of commerce, size of

\footnotetext{
14 John W. Dardess, Confucianism and Autocracy: Professional Ethics in the Founding of the Ming Dynasty (Berkeley: University of California Press, 1983), 164.

15 Pei-Yi Wu, The Confucian's Progress: Autobiographical Writings in Traditional China (Princeton: Princeton University Press, 1990), ix-xii and 235. See also Pei-Yi Wu, "Self-Examination and Confessions of Sins in Traditional China,” Harvard Journal of Asiatic Studies 39 (1979), 5-38.

${ }^{16}$ For an engaging account of the declining years of the Ming, including the failures and general incompetence of various scholar-officials, see Ray Huang, 1587: A Year of No Significance (New Haven: Yale University Press, 1981).
} 
bureaucracy, etc.) did a single intellectual framework establish such an all-encompassing hold over thinking about social behavior., ${ }^{17}$

\section{The Jesuit Mission to China.}

The early Jesuit Francis Xavier was convinced that, because of its dominance in the region, converting China was the key to bringing Christianity to Asia. Recognizing China's long history and many accomplishments, he was a strong proponent of the accommodationist strategy. He foresaw that in order to be successful, missionaries would need to speak Chinese and understand China, to deal as intellectual equals with the Chinese elite. Based on his experience in Japan, he also saw how scientific learning could attract the interest of the educated. However, Francis Xavier died before reaching China, in 1552, the year that Matteo Ricci was born. ${ }^{18}$

Between 1555 and 1583, about twenty-five Jesuits had some very brief contact with China. In 1574, following in the footsteps of Francis Xavier, Alessandro Valignano (1539-1606) became "Visitor" for the Jesuits to the East and thus head of the China mission. Valignano insisted that Jesuit missionaries to China must be intellectually and culturally able to interact with the Chinese elite, and that they immerse themselves in Chinese history and language before beginning their work. The most important of the Jesuit missionaries who arrived under Valignano's supervision was Matteo Ricci—known to the Chinese as Li Madou—who worked in China from 1583 until his death in Beijing in 1610. His approach modeled Jesuit activity in China, and we shall take him as our principal reference point in the analysis that follows.

Ricci was followed in China by other missionary intellectuals, among them the Jesuits Johann Adam Schall von Bell (1592-1666, known as Tang Ruowang) and Ferdinand Verbiest (1623-1688, known as Nan Huairen), who shared their expertise in the disciplines of mathematics, astronomy, and cartography. Although the pace of conversion was very slow, the Jesuits gained the respect of many in the Chinese court. Schall was made director of the Bureau of Astronomy in 1644 and survived the bloody transition from the Ming to the Qing. He became

${ }^{17}$ Gilbert Rozman, “Comparisons of Modern Confucian Values in China and Japan,” in The East Asia Region: Confucian Heritage and Its Modern Adaptation, edited by Gilbert Rozman (Princeton: Princeton University Press, 1991), 162.

${ }^{18}$ In addition to sources cited above, see Charles E. Ronan, SJ, and Bonnie B. C. Oh, eds., East Meets West: The Jesuits in China, 1582-1773 (Chicago: Loyola University Press, 1988); and Jonathan Spence, The Memory Palace of Matteo Ricci (New York: Viking Penguin, 1984). 
very close to the young man who became the first Qing emperor, and it seemed for a while that the emperor would convert to Christianity. However, in 1657, at age19, he became (and remained) a devout Buddhist.

Verbiest succeeded Schall in the Bureau of Astronomy, himself survived a period of persecution, and became an important advisor to the Kangxi emperor, who made use of the Jesuits' astronomical and scientific knowledge in establishing and consolidating the Manchu claim to the Mandate of Heaven. In 1692, the emperor issued an edict of toleration recognizing Christianity as an “indigenous” religion. This success was short-lived, however. The Kangxi emperor insisted on close supervision of the missionaries and required that they accept the practice of reverence for ancestors. When the Vatican refused to allow this, Christianity was again banned in China, although enforcement was sporadic and some Jesuits continued their work underground. The Society of Jesus itself was suppressed by the Vatican in 1773.

\section{Ricci’s Accommodations.}

The accommodationist strategy requires a delicate balance. If practices or beliefs of the foreign culture are accepted that contradict Catholic dogma, the accommodation is theologically invalid. However, if the missionaries reject specific indigenous practices and beliefs, the foreigners may repudiate Catholicism. ${ }^{19}$ Success consists in achieving just the right balance-a lived faith that would be authentically Catholic but, in this case, markedly Chinese.

To illustrate how Matteo Ricci and his successors attempted to achieve this balance, we describe specific accommodations under six titles: lifestyle, indirect speech, translation, convergence, selectivity, and collaboration. ${ }^{20}$ We assume Ricci saw his choices in each area as appropriate and useful for achieving the goal of conversion. As he wrote in one of his letters to a European friend: "Little by little we shall win the confidence of this people and remove all their suspicions, and then we will deal with their conversion.”21 Many of Ricci’s decisions, however, were controversial at the time and raise questions in the present.

\footnotetext{
${ }^{19}$ D. E. Mungello, The Great Encounter of China and the West, 1500-1800 (Lanham: Rowman \& Littlefield, 1999), 13.

20 Joseph Sebes, SJ, discusses four facets of cultural accommodation in "The Precursors of Ricci," in Ronan and Oh (1988), 42-49. We have expanded his list to six, altered some of the categories, and included other activities, so as to highlight the ethics questions that interest us.

${ }^{21}$ Quoted by Albert Chan, SJ, “Late Ming Society and the Jesuit Missionaries,” in Ronan and Oh, 169 n13.
} 
Lifestyle. Ricci lived in China as an intellectual, with a life centered on conversation, writing, and educational pursuits. He was a scholar as well as a priest, with formidable mental powers, a photographic memory, and great facility in foreign languages. He was also charming and physically imposing - indefatigably cheerful but with a bearing that conveyed great authority — with blue eyes and (so it is reported) a voice like a bell. In Europe, he had studied the latest developments in astronomy, cartography, and mechanics, partly with the thought that these could be useful in winning arguments "with Protestants and, conceivably, pagans."22 Before entering China, Ricci spent several years in extended study of Chinese literature and culture, achieving a facility in the language unusual for a European and providing one basis for the respect that the Chinese later afforded him. He learned by heart the Confucian Four BooksGreat Learning, Doctrine of the Mean, Analects, and Mencius - which he translated into Latin, and instructed scholar-officials in the use of mnemonic techniques for memorizing classical texts, which was crucial for success in the civil service examinations.

While these personal qualities and activities served Ricci well with his Chinese audience, he supplemented them in various ways. For example, while Jesuits were not required to wear any special garb or habit, there were three conditions on the choice of clothing: that it be appropriate to a religious identification, that it conform to local custom, and that it reflect the vow of poverty. Jesuits were to be distinguished not so much by their "external habits but by the example of their lives.”23 In Ming China, however, patterns of dress were highly articulated indicators of social status. Robes, hats, belts, shoes, ornaments—all had their special significance in demarcating whether one was a member of the elite or a commoner, a peasant or a merchant, a reclusive monk or a teaching priest, a member of the top rank of civil officials or one of the lower eight ranks—each with its own colors, fabrics, insignias, and the like. ${ }^{24}$

\footnotetext{
${ }^{22}$ Willard J. Peterson, "What to wear? Observation and participation by Jesuit missionaries in late Ming society," in Implicit Understandings: Observing, Reporting, and Reflecting on the Encounters Between Europeans and Other Peoples in the Early Modern Era, edited by Stuart B. Schwartz (Cambridge, Eng.: Cambridge University Press, 1994), 410.

${ }^{23}$ Quoted by O’Malley, 341, from Juan Alfonso de Polanco.

${ }^{24}$ Peterson (1994), 403ff. Note Confucius' detailed prescriptions for the clothes of the exemplary person in Analects, chapter 10. Quotations from the Analects are from Simon Leys' translation, unless otherwise noted.
} 
When Ricci first arrived in China, he followed Xavier's model in Japan and fashioned himself after mendicant Buddhist monks. He shaved his head and face and donned a long, brown, cotton robe, thinking this mode of dress would generate respect and open doors for the message he wished to deliver. Ricci soon learned that, unlike attitudes in Japan, the Chinese elite did not esteem Buddhist monks, so after several years he requested permission from Valignano to change his accouterments. Instead Ricci adopted the ways of scholar-officials, patterning his dress, food, and habits on theirs-including their contempt for Buddhists. He stopped shaving his head, wore purple silk robes, kept his nails well trimmed, and eventually let himself be carried in a palanquin (sedan chair) accompanied by a retinue of servants. "My prestige," he commented, "is greatly enhanced when I go visiting.,"25

Ricci’s Jesuit colleague Michele Ruggieri had declared some years earlier that he had "become Chinese in order to win China for Christ." ${ }^{26}$ Ricci, we believe, never thought he had become Chinese. But he dearly wished to be accepted as an equal by scholar-officials. Once he established residence in Beijing in 1601, Ricci had constant and wide-ranging exchanges with members of the mandarin elite. He acknowledged that his respect among the Chinese came from his command of their language, his memory, his knowledge of mathematics and science, the "curious objects" he had brought from the west, and his acquaintance with alchemy. Sixth on the list of reasons for respect was his religious teaching.

No doubt, Ricci's personal integrity and rectitude contributed to the perception of Christianity as a compelling and morally uplifting religion. Ricci himself was aware that, with all the obstacles to this cross-cultural endeavor, the most direct form of teaching "this pagan people” was "by virtue of [our] example and by the sanctity of [our] lives." In this way, he attempted "to dispose their minds to receive what they could not be persuaded to accept by word of mouth." ${ }^{, 27}$ What exactly is exemplified, however, if one is becoming pagan in order to convert pagan people to Christianity? Is the message clear? The cruelties of Ming governance caused many scholar-officials to withdraw from political life, even if they remained in office, and become preoccupied by the pursuit of personal moral perfection. For them, Ricci was a potential

\footnotetext{
${ }^{25}$ Peterson (1994), 414.

${ }^{26}$ Ibid., 409.

${ }^{27}$ Spence, To Change China, 7.
} 
model. On the other hand, many were fully aware of the Jesuits's machinations and not taken in by them. ${ }^{28}$

Ricci's lifestyle choices were questioned within the Society of Jesus and strongly criticized by Franciscan and Dominican missionaries to China, especially regarding the vow of poverty, which was central to the aspiration to model one's life on that of Jesus. For Ignatius, voluntary poverty was a crucial part of the Jesuit way of proceeding. But how did voluntary poverty relate to effectiveness in mission? For Ricci, the key to conversion of China was conversion of the elite; the key to conversion of the elite was to become one of their circle. The result was a flexible interpretation of religious identification and of the vow of poverty.

Indirect speech. In employing his conversational skills, Ricci was a faithful disciple of Ignatius and his early followers. Taking their cue from some remarks by Ignatius, the early Jesuit writers Jeronimo Nadal and Peter Canisius developed the notion that conversation is an important precursor to presenting the dogmas of Catholicism to potential converts. In conversation, one approaches individuals with love and a desire for their well-being, carefully observing each person's temperament and character and attempting to enter gently into their thoughts. $^{29}$ The conversation begins with subjects of interest to the other person; for example, with a merchant one speaks of trade, with a nobleman of government. Only gradually does one bring the discussion around to spiritual matters. So understood, conversation is not so much an art as a pastoral tactic, implying (O’Malley observes) calculation and control. It exemplifies the Spanish proverb Ignatius often quoted: “Go in by their door in order to come out by ours.”

With Ricci, both his knowledge of western natural philosophy (as the latest developments in science and technology were called) and his mastery of Chinese texts afforded him entrée into Chinese intellectual life. Further, the mechanical devices he had brought with him from Europe, such as clocks, prisms, and astrolabes, attracted the interest of the mandarins, as did his books, maps, and musical instruments. In the world maps Ricci had brought with him, following a standard $16^{\text {th }}$ century pattern, Jerusalem was at the center, Europe on the left-hand edge, and China far to the right. When his interlocutors asked him to reproduce a map with the

\footnotetext{
${ }^{28}$ Joanna Waley-Cohen, The Sextants of Beijing: Global Currents in Chinese History (New York: W. W. Norton, 1999), 57 and 70.

${ }^{29}$ O’Malley, 110-115.
} 
geographical names in Chinese, he relocated China to the center, thus affirming the Chinese view of their country as the Middle Kingdom.

Ricci used western science and especially astronomy to make his religious message more attractive. (In this respect, as in others, Ricci engaged in what our colleague Joseph Nye would call an exercise of soft power.) Here the Chinese were especially vulnerable, since they regarded the human social order as an integral part of the cosmic natural order. Astronomy and calendrical science were enormously important in China, as Jonathan Spence points out, because "almost all facets of life ran to the rhythm of the lunar months and auspicious days."30 Planting and harvesting, festivals and funerals, political and judicial decisions-everything could potentially undermine the legitimacy of the emperor, who had the responsibility to mediate between heaven and earth. A country that had flourished for centuries on the wisdom of ancient sages was suddenly exposed to people with new — and more reliable-knowledge.

In a report home, Ricci observed that, if the Jesuits had an opportunity to correct the Chinese calendar, “this would enhance our reputation [and] give us freer entry into China.”31 When Adam Schall later became director of the Bureau of Astronomy, he managed to display, to the satisfaction of Chinese officials, that his grasp of astronomy-for example, his ability to predict eclipses - was superior to that of Chinese and Islamic astronomers employed by the imperial court. Schall's efforts had the effect that Ricci anticipated, that is, they opened doors and created opportunities to give advice. Yet, considering that mere claims to superior knowledge, even valid claims, are rarely the primary determinants of political action, it is not surprising to learn that Schall could maintain his influence only by engaging in constant political intrigue. $^{32}$

Perhaps little is amiss in using genuine new knowledge to gain a hearing. However, Ricci’s efforts were even more problematic, as we shall see. Some of the new scientific developments — such as emerging heliocentric theories — were actively suppressed, and the Jesuits used astrology as readily as they used new science.

\footnotetext{
30 Spence, To Change China, 9.

31 Ibid., 8.

32 Benjamin A. Elman, On Their Own Terms: Science in China, 1550-1900 (Cambridge: Harvard University Press, 2005), 133-144.
} 
Translation. Conversion to the Catholic faith was (and is) signaled by the rite of baptism and by the voluntary profession of belief in basic Christian doctrines: creation, incarnation, salvation through the cross, resurrection, judgment, and so on. To say the profession of belief is voluntary means not only that belief is not coerced but, presumably, that one is not tricked into it, either. That, in turn, means it is necessary for converts to understand the quite precise formulations of the doctrines that define the orthodoxy of the times. In Ricci's case, the concepts and doctrines had to be translated into the Chinese language and somehow made accessible in the context of Chinese culture.

Ricci was aware that Chinese scholar-officials regarded their Confucian heritage as superior to anything the West had to offer. He wanted, therefore, to tie Christian to Confucian concepts, to portray Christianity as consistent with and to some extent a fulfillment or perfected form of true Confucianism. Accordingly, he looked for linguistic and conceptual analogues to Christian doctrines in the Confucian texts, arguing, for example, that early Confucianism had held an idea of a personal creator god that had been corrupted by later thinking but could be found again in Christian belief. Thus, Confucian texts were read as prefiguring theological ideas. The terms Ricci used for the Christian God, "the Lord of Heaven" [Tianzhu] or "the Lord on high" [Shangdi], employed classic Chinese words for heaven and supreme lord. ${ }^{33}$

Ricci's aim was to interpret Confucius and other Chinese authors "in such a way that they follow our ideas." ${ }^{34}$ In this regard, Ricci's “willful interpretive process,” in Benjamin Elman's words, resembled a tactic common among Christian humanists of the Renaissance, who found fragments of natural theology in the pagan texts of ancient Greece and Rome. ${ }^{35}$ Yet, Ricci was aware that the use of Chinese concepts and characters to explain Christian truths was not without

${ }^{33}$ For a general discussion of ancient Chinese "religion," including ancestral spirits, nature divinities, and the "high god" Shangdi, see Benjamin I. Schwartz, The World of Thought in Ancient China (Cambridge: Harvard University Press, 1985), chapters 1 and 2.

${ }^{34}$ From a 1604 letter to Claudio Acquaviva, Ricci’s superior in Rome, quoted by Lionel M. Jensen, Manufacturing Confucianism: Chinese Traditions and Universal Civilization (Durham: Duke University Press, 1997), 97. Along the same lines, in a 1609 letter to Fr Francesco Pasio, the vice-provincial of Japan, Ricci wrote: "I have avoided criticizing [basic Confucian doctrine] but have sought to interpret it where it appears to conflict with our holy faith." Quoted by D. E. Mungello, Curious Land: Jesuit Accommodation and The Origins of Sinology (Honolulu: University of Hawaii Press, 1989), 63.

35 Elman, 114, 120. Paul Rule observes that the ancient Confucian texts that Ricci favored present a limiting case, since "the religious or sacred elements are elusive." Paul A. Rule, K'ung-tzu or Confucius? The Jesuit interpretation of Confucianism (Sydney: Allen \& Unwin, 1986), xiii. One might ask, however, whether the interpretive process need be any more willful than Aquinas's synthesis of Christianity and Aristotle. 
problems. The principal concern was that in using Chinese terms to express non-Chinese concepts, the concepts would be altered and distinctions and nuances lost. One question, for example, was whether the god of ancient Confucianism, if indeed there was a single god, could be reinterpreted as the Christian God, or whether Ricci was inadvertently sanctioning some heretical belief. In Japan, Francis Xavier had at first used a Buddhist term that in fact referred to a pantheistic concept to identify the Christian God. After Xavier recognized his mistake, he reverted to traditional Latin and Portuguese terms for the Christian dogmas. Ricci, arguably, was at risk of making the same kind of error. According to standard accounts, the sacred and the mundane are not distinct in classical Chinese. Tian [heaven] does not transcend the world; it encompasses the human world as well as the natural environment, which are interdependent. ${ }^{36}$ Ricci’s linguistic choices were affirmed by the Society initially, but in 1704 Pope Clement XI prohibited their use.

When Ricci felt he had mastered the Chinese language sufficiently, he began writing a book “presenting our faith according to natural reason.” Ricci's The True Meaning of the Lord of Heaven is an attempt to explain Christian doctrine through a dialogue between a Chinese scholar-official and a Western intellectual. In language that is characteristically learned and elegant (as fine, it was said, as anything written by his Chinese associates), the dialogue deals with creation, incarnation, and redemption through philosophical arguments that reflect Chinese ways of thinking. The use of "natural reason" to persuade others of the truth of fundamental beliefs was not novel in Catholic theology. In the $13^{\text {th }}$ century, Aquinas distinguished between doctrines that could be understood by the light of reason and thus were accessible to everyone (such as the existence of God) and doctrines that required special revelation (such as redemption and the incarnation of Christ). Ricci's method was thus not unprecedented, even if he may have shifted the line between what is available to reason and what is not.

Convergence. Ricci's reliance on natural reason was an implicit concession that the Chinese were of equal intellectual ability as their visitors. But it brought into play two challenges. First, what to do if his Chinese interlocutors were not rationally persuaded by the arguments? Suppose they presented compelling counterarguments of their own. Were the

\footnotetext{
${ }^{36}$ Roger T. Ames and Henry Rosemont, Jr., The Analects of Confucius: A Philosophical Translation (New York: Random House, 1998), 46-47.
} 
Jesuits themselves open to reasoned persuasion? (An alternative to conversion is genuine reciprocal engagement with another culture. We shall return to this idea below.) Second, what about the other crucial doctrines not available to natural reason? It would require, presumably, subtle non-rational techniques to make these doctrines compelling. A striking feature of Ricci's method is the use of rhetoric and emotional appeals, which were part of the accommodationist strategy. ${ }^{37}$ How does the use of rhetoric fit with natural reason and the voluntary profession of belief?

To take the second set of questions first, we should note that "rhetoric" often conjures up images of politicians and media pundits who will say anything to attract a following or please an audience. A more nuanced view is that skill in rhetoric is the ability to argue either side of a question - the kind of skill that good debaters possess, not to mention lawyers whom we know are meant to be zealous advocates for their clients without necessarily believing anything they say. We would distinguish these problematic images from the idea of rhetoric as a form of nonrational persuasion. Sometimes a speaker's influence is enhanced by eloquence or the imaginative use of language, while leaving listeners free to make up their own minds. Such uses do not involve misrepresentation or deception but are sincere efforts at persuasion. The issue to consider is whether the Jesuits adhered to this third idea or took on the posture of zealous advocates.

Regarding the first set of questions, we believe it is important to recognize that Ricci's harmonizing of Christianity and Confucianism may not have been just a tactic designed to bring about conversion of the Chinese, but may have been motivated in part by deeply-felt appreciation of Confucian thought. Confucian China, we believe, challenged the moral selfconfidence of this western elite. What Ricci and other Jesuits saw in Chinese civilizationapparently much to their surprise - was a highly sophisticated naturalistic ethic that could be the envy of Europe. Did they experience a corresponding self-doubt? If so, it would not likely be revealed in any reports or missives sent to Europe, only in a tone of warm appreciation in discussing the Confucian texts.

${ }^{37}$ O’Malley, 255-256. 
Seventeenth Century European scholars who noticed this tone and were impressed by Jesuit enthusiasm for China focused much of their attention on Confucian ethics. ${ }^{38}$ Although coming somewhat later, the admiration of the German polymath Gottfried Wilhelm Leibniz (1646-1716) was typical. While taking pride in European superiority in theoretical disciplines (from theology to logic and mathematics), Leibniz remarked on the deficiencies in ethics:

"[W]ho would have believed that there is on earth a people who, though we are in our view so very advanced in every branch of behavior, still surpass us in comprehending the precepts of civil life? Yet now we find this to be so among the Chinese.... And so if we are their equals in the industrial arts, and ahead of them in contemplative sciences, certainly they surpass us (though it is almost shameful to confess this) in practical philosophy, that is, in the precepts of ethics and politics adapted to the present life and use of mortals."

Striking a characteristic note on the value of harmony, Leibniz marveled at how beautifully Chinese laws, "in contrast to those of other peoples, are directed to the achievement of public tranquility and the establishment of social order, so that men shall be disrupted in their relations as little as possible.” Accordingly, he professed his desire for reverse missionary work: "Certainly the condition of our affairs, slipping as we are into ever greater corruption, seems to be such that we need missionaries from the Chinese who might teach us the use and practice of natural religion, just as we have sent them teachers of revealed theology. ${ }^{\text {„39 }}$

What Leibniz saw in Confucianism, following Ricci, was a profound exercise of natural reason. In Ricci's words: "When we examine the [Confucian] texts closely, we discover in them very few things which are contrary to the light of reason and many which are in conformity with

\footnotetext{
38 This may be the place to note that Jesuits invented the term "Confucian.” The name "Confucius" is a latinization of Kongzi ("Master Kong”) or, more specifically, Kong Fuzi (“our Master Kong”). The Chinese refer, rather, to Ru ("scholars") and Rujia ("the school of scholars") and their learning as Ruxue.

${ }^{39}$ Gottfried Wilhelm Leibniz, Writings on China, translated by Daniel J. Cook and Henry Rosemont, Jr. (Chicago: Open Court, 1994), 46, 47, and 51. Leibniz's enthusiasm for Confucian ethics was shared by Voltaire, but the seeds of disillusion began to appear in a number of $18^{\text {th }}$ century European writers as more was learned about Chinese society through first-hand reports.
} 
it." 40 This is possible because the natural laws of ethics are inscribed in all human hearts. Thus, it is not just a matter of finding parallels between Confucianism and Christianity but detecting a real convergence. Confucianism is not false but complementary to Catholicism and therefore available for dialogue. At the same time, Christianity provides a metaphysical foundation otherwise missing in a purely naturalistic approach.

To regard Confucianism as a naturalistic ethic, however, Ricci had to reject the neoConfucian cosmology that had become an integral part of Chinese orthodoxy since the Song dynasty, especially under the influence of Zhu Xi (1130-1200). This amalgam included large doses of Buddhist and Daoist metaphysical speculation that conflicted with Christian doctrine. Instead, Ricci proposed returning to the original Confucian texts, with their apparent agnosticism about spiritual things. ("The topics the Master did not speak of were prodigies, force, disorder and gods.” [Analects 7.21, Lau translation]) In this regard, we note a dovetailing between the Jesuit accommodationist project and the views of some scholar-officials, who were looking for a way to exhibit more independence from the prevailing orthodoxy. Xu Guangqi (1562-1633), one of the most eminent of Ricci's converts, captured the view succinctly with the phrase “supplement Confucianism, displace Buddhism” [bu Ru yi Fo]. ${ }^{41}$

Textual harmonization is a risky strategy, especially when one is attempting to make the case to individuals deeply versed in the original literature who could easily spot discrepancies and distortions. One might expect agreement on the golden rule, for example, which appears several times in the Analects. But if Ricci had proposed turning the other cheek, the mandarin elite might recall 14.34: “Someone said: 'To repay with kindness-what do you think of that?' The Master said: “And what will you repay kindness with? Rather repay hatred with justice, and kindness with kindness.” (This theme is continued in 17.24, where Confucius expounds the appropriate hatreds of the exemplary person.)

\footnotetext{
40 Michael Puett, The Ambivalence of Creation: Debates Concerning Innovation and Artifice in Early China (Stanford: Stanford University Press, 2001), 4.

41 Mungello, Great Encounter, 17. It should be noted that, like the Japanese, the Chinese did not regard religious systems as necessarily incompatible with one another. As Mungello observes elsewhere: “A scholar-official might be impeccably Confucian in his public life, practice Taoist longevity techniques in his private life and bury his parents with Buddhist rites.” Curious Land, 55. The statement in the text, therefore, already expresses Christian exclusivity.
} 
At any rate, among scholar-officials at the time, traditional values were widely perceived to be eroding. Many intellectuals were less committed to Confucian orthodoxy than in other periods and were looking for new ways, new arguments, to support the old values of filial piety and service to the ruler. They were thus surprisingly open to blending Christian with Confucian principles, in the search for a new synthesis. Intellectually, both sides could conceive of a synthesis because Confucianism's emphasis on individual moral cultivation was not incompatible with Christianity's focus on spiritual matters. Ricci's essays on friendship and on "the extraordinary man” spoke to this search for synthesis. He presented Christianity as providing rules that came from the Lord of Heaven and that affirmed at least some of the old values, setting a solid foundation for a moral society. The appeal to a transcendent source of familiar moral values figured prominently in the conversion accounts of some elite Chinese.

Selectivity. The Jesuits introduced more accurate maps and calendars than the Chinese possessed up to that point. Calendars were especially important, as we have noted, since the Chinese believed that events were governed by the stars and needed to be planned in accordance with astrological signs. Ricci's successors established their usefulness not only by collaborating with court astrologers in predicting solar and lunar eclipses but engaging in hemerology, that is, the choice of auspicious days. Despite their own skepticism, they recognized the importance of hemerology for the imperial court-and hence for maintaining their own credibility as advisors to the emperor. Ricci himself acquired a reputation as a practitioner of alchemy, though perhaps that had more to do with uninformed expectations about western science than his actual participation in that art. At any rate, in demonstrating their own usefulness, and thus the alleged usefulness of the Christian faith, the Jesuits introduced good science and mixed it with superstition, as they must have known.

These activities appear to violate the commitment to natural reason. Indeed their own clarity about the true epistemic status of these beliefs probably facilitated the Jesuits' ability to manipulate them for their ends. The esteem they garnered came from their place in the prevailing Chinese worldview, but the Jesuits could not participate in that worldview without condescension and trickery. A clear example is Jesuit suppression of the various heliocentric theories then gaining a foothold in Europe, including the Copernican theory which had appeared in 1543. The Pope had condemned it as heretical, which might be reason enough not to mention 
it, but apparently the crucial worry was that it would complicate the effort to offer a clear, consistent, and thus credible picture of the universe-at a time when new discoveries were continually unsettling everyone's assumptions. ${ }^{42}$ To their consternation, the Jesuits were not the only source of information about intellectual controversies in Europe. Some scholar-officials were in a position to criticize Jesuit teachings because they knew about scientific discoveries that the Jesuits were suppressing. ${ }^{43}$

There was also the danger of the strategy backfiring. In 1664, the scholar-official Yang Guangxian accused Adam Schall of causing the death of the Shunzhi emperor's favorite concubine and, out of grief, the premature death of the emperor himself. (They both died of smallpox.) This happened because Schall, as head of the Bureau of Astronomy, had selected an inauspicious day for the burial of the child born to the two of them. In the subsequent investigation, the 73-year-old Schall suffered a stroke, became paralyzed, and lost the ability to speak. He was carried to the proceedings on a stretcher, found guilty, and along with his seven Chinese assistants sentenced to a lingering death. Later, five more Chinese were sentenced to death, and the three other Jesuits in Beijing were sentenced to flogging and exile. On the very next day, however, there was an earthquake in Beijing and a fire in the palace, which were interpreted as signs of Heaven's displeasure with the verdicts. Everyone was freed, except for five Chinese Christian astronomers who were blamed for choosing the inauspicious day and were executed. ${ }^{44}$

Even religious doctrine was manipulated by the Jesuits. Christian insistence on strict monogamy was foreign to elite Chinese culture. Reluctance to leave their concubines was a clear barrier to conversion for many members of the court and the mandarin class. The Jesuits did not insist. Also, scholar-officials resisted the doctrines of the crucifixion and resurrection of Christ, because the notion that the human being who was the incarnation of God would subject himself to extreme physical violence contravened the social distinctions they took for granted.

\footnotetext{
${ }^{42}$ Waley-Cohen, 108.

${ }^{43}$ See Willard J. Peterson, “Fang I-chih: Western Learning and the 'Investigation of Things,'” in The Unfolding of Neo-Confucianism, edited by William T. de Bary (New York: Columbia University Press, 1975), especially 385388.

${ }^{44}$ Mungello, Great Encounter, 44; Elman, 136ff.
} 
Such degrading punishment was associated in their eyes with the lower classes. ${ }^{45}$ Given the cosmic links between human conduct and natural events, one has to believe that scholar-officials were inclined to the view that virtue is visibly rewarded in this life, not the hereafter, by the special treatment that goes with high social status. The virtuous prosper; the wicked do not. ${ }^{46}$ Accordingly, Ricci and later Jesuits de-emphasized the crucifixion and resurrection in their instruction to prospective converts.

In the opposite direction, Ricci’s accommodationist strategy extended to liturgy, which he conducted in the Chinese language and Chinese dress. The most controversial aspect was his willingness to incorporate the tradition of ancestor veneration into Christian worship. Filial piety, directed at parents, ancestors, and legal authorities, was central to Chinese ethics. The question was whether these rituals represented idolatry or superstition of a sort that compromised Christian belief. Under one interpretation of the Chinese tradition, ancestral spirits exist as conscious beings and are able to respond to the pleas of the living by bestowing good fortune. Accordingly, filial duties often included sacrificial offerings, kowtowing, and what looked very much like petitionary prayer.

Ricci convinced himself, and for a time others, that these rituals represented veneration in a secular sense. In this view, exhibited in the Analects, the rituals embody a certain attitude toward ancestors, expressing indebtedness or gratitude for one’s existence, not worship—and could therefore be permitted to Christians. Ricci’s conception, at any rate, represented a very important concession; for, without it Christianity would not make any progress in China at all. (Ricci’s view anticipates contemporary functional understandings. In Tu Wei-ming's terms: “The dead are honored, because a loving memory of the forefathers brings forth communal identity and social solidarity."47) We do not know Ricci’s mind with any certainty on this matter, but we assume he knew that tolerance of ancestor veneration bordered on heresy, at a time when purity of doctrine and ritual was of great concern to the institutional Catholic Church. At any rate, the Jesuits did get away with this stance for quite a long time, until in 1709 and 1715

\footnotetext{
45 Mungello, ibid., 21.

46 Paraphrasing David Keightley as quoted by Michael Puett, The Ambivalence of Creation: Debates Concerning Innovation and Artifice in Early China (Stanford: Stanford University Press, 2001), 13.

47 Tu Wei-Ming, Centrality and Commonality: An Essay on Confucian Religiousness (Albany: State University Press of New York, 1989), 48.
} 
Pope Clement XI issued papal bulls in favor of the Dominicans, who had challenged the Jesuits on many aspects of their missionary work. He decreed that Catholics could not be permitted to participate in ancestor worship, even at home, or even as passive bystanders at a funeral, since "[s]uch a ritual is heathen in nature regardless of the circumstances." This decree elicited a strong reaction in China; the emperor banned all Christian missions. ${ }^{48}$

Collaboration. Finally, we want to ask about the use of tactics that rely on identification and collaboration with political and social elites. Such identification was perhaps automatic for the Jesuits, since they tended to come from prominent European families and were accustomed to operating at the highest levels of society. However, hobnobbing with privileged members of society has its dangers; it means, for instance, taking on their problems as one's own.

One set of problems that Ricci and his successors spoke to in their attempts to persuade the Chinese elite of the value of Christianity had to do with social order. The times were transitional and chaotic; many Chinese, as we have observed, were looking for a solid and authoritative basis for the traditional values of filial piety and deference to authority. In making their arguments, however, at least some of the Jesuits exaggerated the moral effects of Christianity, playing down the religious warfare then consuming Christian Europe, presenting it as more peaceful and harmonious than it actually was. (The doctrinal squabbles among different missionary groups in China—a great puzzle to the Chinese-further called into question some of their claims.)

To rely on social efficacy as an argument for Catholic belief—a solution to civil disharmony and moral breakdown—seems disingenuous in itself, given the history of Christianity. In the context of China, it fed into the superstitious belief that religious ritual is a resource for averting natural calamities, such as earthquakes or famines, a belief the Jesuits themselves did not accept. (Unbelief, or mistaken belief, could have serious consequences for a Christian, but they were consequences for individuals and their eternal happiness.) The Jesuits did their work in China, of course, before the European religious wars had played themselves out

\footnotetext{
48 There is a large literature on what is known as "the Chinese rites controversy." See, for example, Paul A. Rule, cited at note 35. In 1939, Pope Pius XII rescinded the decrees of Clement XI, and in 2001, during ceremonies marking the $400^{\text {th }}$ anniversary of Ricci's arrival in Beijing, John Paul II apologized directly to the Chinese for wrongs committed by members of the Church, saying: "I regret that in many people these failings may have given the impression of a lack of respect and esteem for the Chinese people.” Quoted by Thomas C. Fox, Pentecost in Asia: A New Way of Being Church (Maryknoll: Orbis, 2002), 196.
} 
fully. It took several centuries for the Europeans to realize that people of fundamentally differing faiths can live in peace with one another.

Jesuit attempts to address the Court's concerns became even more dubious with the activities of Ricci's successors. The late Ming dynasty was threatened both by internal bandits and by Manchu invaders from the north. Adam Schall was asked by the emperor to provide plans for and assist in the construction of cannon to be used against the northern invaders. He did so as a way of currying favor with the emperor, thereby contributing to massive death and destruction — not to mention that he ended up on the losing side. After the Manchu conquerors consolidated their power, they sought to establish their legitimacy through knowledge of the stars; Schall was able to contribute to this endeavor and gain influence at the new court. His successor, Ferdinand Verbiest, was also asked to help construct cannon, and became vice president of the board of works with responsibility for armaments. He gave each cannon he produced the name of a saint and blessed it. (Among the various inscriptions on Verbiest's tomb in the Zhalan cemetery is this: "Able to Deal in Spiritual Matters, He Was Also Able to Provide Armaments.”)

Schall and Verbiest were assisting the court in defending itself from northern aggressors. Their utilitarian reasons for doing so, and the ease with which Schall switched sides when the outcome became clear, lead us to ask whether these means are consistent with a commitment to establishing God's just and peaceful kingdom on earth.

The easy switch of loyalty to the new regime was also a betrayal of many of the scholarofficials, who regarded loyalty to their Ming superiors (however difficult the relationship) as irrevocable. Ricci's successors calculated that the new emperor would be a more effective ally in their efforts at conversion than the mandarin elite. As noted, Adam Schall was a tutor to the young man who became the first Qing emperor, and it seemed for a while that the emperor would convert to Christianity. Schall's failure is emblematic of the general failure of the Jesuit enterprise. The irony is that the new Manchu rulers, attempting to secure their own legitimacy, made a deliberate effort to embrace Confucian values, the Chinese language, and the existing scholar-official system —an accommodationist strategy of their own, with somewhat different aims.

In making their case to the elite, the Jesuits argued that Christianity was not a threat to important Chinese cultural values. This stance was also disingenuous, since the Jesuits aimed to 
displace an all-encompassing political authority (in the hands of the emperor) with their own allencompassing religious authority. But taken in the best light, the Jesuits recognized the richness of Chinese civilization and believed that the basic truths and practices of Christianity could be disentangled from the European cultural trappings in which they had traditionally been wrapped. They argued that Christianity and Confucianism were complementary, not in competition. As we have emphasized, Ricci found analogues to Christian concepts of God in the Confucian classics. He drew ethical parallels and argued for convergence. He conducted liturgy using the Chinese language, gestures, and dress, incorporating the veneration of ancestors.

This approach contrasted sharply with the missionaries who accompanied or followed the Spanish and Portuguese conquerors to the Americas, bringing Christianity by force. They treated the Catholic religion and European culture as a unity; they meant to bring the whole package to the indigenous populations whom they saw as both pagan and barbarian. (They embodied the ethos of the Reconquista by which Jews and Muslims in Spain had been forcibly converted or expelled.) Ricci and his successors had a more sophisticated approach. To the extent that they exploited elements of European culture-particularly the developments in science and technology - they viewed them (at least in their better moments) not just as tools that might induce the Chinese to develop a positive regard for Christianity, but as advances in knowledge that would contribute to intellectual achievement in China-all the while respecting the integrity of Chinese civilization.

Except that “integrity” was a complicated matter in a many-sided culture like China’s. The Jesuits were taking sides. They were taking sides, for example, on the question of political reform, favoring defenders of the imperial status quo over dissidents. Regarding these dissidents, William T. de Bary observes: “[T]here could be no sharper contrast than that between the appreciative, indeed enthusiastic, accounts of China by early Jesuits in the sixteenth and seventeenth centuries and the severe criticism of Chinese institutions by contemporary [dissident] Confucians of the seventeenth century,” such as Huang Zongxi, who argued for devolution of power away from the court and to local communities. ${ }^{49}$

Collaboration meant working against the common people, who were more likely than the elite to be adherents of Buddhism or Daoism. Jesuit willingness to make common cause with

\footnotetext{
49 Huang Zongxi, Waiting for the Dawn: A Plan for the Prince, translated by William T. de Bary (New York: Columbia University Press, 1993), 3.
} 
scholar-officials in denigrating these faiths alienated them from the people who might well be regarded as their rightful constituency. Indeed, the problems that the Jesuits agreed to work on-astronomy, the decline of values, foreign invasion-were not the only problems facing China at the close of the Ming and the beginning of the Qing dynasties. Population had been growing for several centuries; arable land was scarce; agricultural productivity had improved but barely enough to keep up with population growth. Government in the provinces was often exploitative and corrupt. The lavish imperial court in Beijing was built with money and labor appropriated from a very poor peasantry.

In focusing on the problems of the elite, the Jesuits were at best ignoring and at worst contributing to the plight of the poor. An approach to missionary work that harms or fails to help the poor can be criticized on both religious and secular grounds. Jesus articulated his own mission as one of bringing "good news to the poor." Presumably, Christian missionaries ought to follow his example. For those who work with elites, the burden of proof is on them to show that their activities have more general benefits.

\section{The Ends and Means of Missionary Work.}

The activities of the Jesuits in China raise a number of issues that fall, roughly, into questions about ends and about means. One set of questions has to do with the nature of the missionary goal; the other concerns methods used to attain the goal. This division is rough because ends and means interact and involve each other.

In general terms, the Jesuit missionaries to China had a clear goal: to convert the Chinese to Catholic Christianity. They wanted the emperor to be baptized and to make China a Catholic country. Perhaps the model they had in mind was the Christendom of the West as established in the $4^{\text {th }}$ century by the emperor Constantine but seriously threatened in Europe by the

Reformation. Protestant confessions were putting down roots independently of the Church, and fierce battles were raging, figuratively and literally, for the soul of Europe. These struggles often turned on the decision of a prince or political leader. When the prince became or remained Protestant or Catholic, the country, through a combination of intimidation and example, often followed.

The hope was that Catholicism would be established as at least one of the official religions of China, if not the only one. This would, in their thinking, be an appropriate response 
to the instruction of Jesus to "make disciples of all nations," and would result in many souls helped to salvation - the primary intent of Ignatius. Thus, the Jesuits would have looked for large-scale conversions marked by many baptisms and the establishment of many local churches where the Catholic creed was professed, the Eucharist celebrated, and virtuous life, of a Catholic sort, practiced.

In a more specific but perhaps less overt sense, the goal of the missionaries was to displace the mandarin elite as moral advisors to the Chinese emperor. Or at least to revise scholar-officials' understanding of what success in this endeavor should mean. The Jesuits believed they had superior advice to give to the emperor, based on a more certain grasp of the truth about human happiness. They believed, too, that they had the professional skills to succeed as advisors, because they could frame their advice so as to win the emperor's confidence, through the various indirect methods of persuasion that made up the accommodationist strategy.

If the criterion of success was conversion, the project has to be regarded largely as a failure. The emperor did not convert. Some scholar-officials became converts (and some commoners), but not very many as a proportion of their numbers. ${ }^{50}$ And when the Pope decreed that the Church would not accommodate ancestor veneration, the Jesuits were expelled from China altogether.

This outcome, like so much of Ricci’s behavior, suggests that the Jesuit strategy of accommodation was deeply problematic. The Vatican, for its part, held the view that key components of accommodation came too close to heresy, and papal decrees of 1709 and later explicitly repudiated the strategy. We shall argue, however, that a reasoned assessment of accommodationism has to be more nuanced. O’Malley's observation that Jesuit activities in China could be separated sometimes only by a hair's breadth from opportunism is no doubt correct. But the problem was not only in the accommodation strategy itself. The deeper problem, we believe, was the goal of conversion-which leads us to ask a fundamental question about missionary work.

\footnotetext{
50 On the question about numbers of converts, see Liam Matthew Brockey, Journey to the East: The Jesuit Mission To China, 1579-1724 (Cambridge: Harvard University Press, 2007). Brockey’s aim is to shift the story of the mission from a focus on the relationship between Jesuits and mandarins to a focus on commoners. His claim is that Ricci was sufficiently successful in establishing good relations with scholar-officials to provide official protection to subsequent missionaries to engage in ordinary evangelizing.
} 
Counsels of prudence. A basic premise of missionary work is that the beliefs and practices of the host population are deficient in crucial ways and in need of correction. Hence, a censorious stance in relation to these people is inherent in the missionary enterprise, with a corresponding desire to correct their deficiencies. The underlying premise is that what is being advocated is a universal good, something needed (even desired) by all human beings.

In a moment, we shall critique this stance, but if it is accepted, we can at least understand accommodation as a prudential strategy. Ignatius himself had warned how missionaries could do harm to others by insisting that the others follow in the missionaries' ways. ${ }^{51}$ His caution was not about the "universal good" of conversion to Christianity but about the "insisting."

In the case of China, we need to recall that, in the encounter between the Jesuits and the scholar-officials, both sides assumed their own cultural superiority. In such a situation, even if locals agreed there were faults in need of correction, they were likely to believe they were better positioned to improve the existing state of affairs, without outside interference. So, it is reasonable for missionaries to adopt a strategy that tempers the pursuit of their goal, with the aim of increasing their influence and ultimate effectiveness. This thought is reinforced by the observation that intervention may threaten existing balances of power, and thus is likely to disadvantage some groups to the benefit of others-including the missionaries themselves, as the examples of Schall and Verbiest show.

The scholar-officials had their own prudential reasons for openness to Christianity, which they saw as a vehicle for countering Buddhist and Daoist influences in the prevailing Confucian orthodoxy. However, despite initial acceptance of the Jesuit presence in the Qing dynasty, the new rulers came to reject the syncretism of the late Ming and returned to more traditional strands of Confucianism. As the regime advanced, it was increasingly less receptive to Christian ideas, just as it was less receptive to Buddhism and Daoism.

Ignatius's advice here is only prudential because it does not reach the theological (or psychological) questions lurking in the desire to get others to do what "we" believe is right. Beginning in the Reformation period and continuing for several centuries, prudence was the measure of the Church's relation to the nonfaithful. Traditionally, it had been acceptable, even virtuous, for the Church to collaborate with state authorities in coercing heretics to recant their

51 O’Malley, 131. 
deviant ways and return to the fold —or pay the penalty. In a notorious passage, Aquinas advocated the execution of heretics on the ground that it is far graver to corrupt the faith than to counterfeit money. The latter, at least, sustains life, whereas the former destroys the soul. Since it is just to put forgers to death (as was commonly done in the $12^{\text {th }}$ century), unrepentant heretics may be dealt with similarly. "God may pardon them; the Church and the State should not." 52

After the Reformation, practice changed but not doctrine; the attitude to heretics came to resemble the attitude to infidels, i.e., those who stood outside the Church altogether. The Church abstained from religious persecution and practiced toleration, but it regarded toleration as an evil—a lesser evil in the circumstances. Religious freedom was not an ideal; untruth had no rights. In an ideal world, collaboration with the state would continue, in order to guarantee orthodox belief.

The ethics of conversion. Only with the Second Vatican Council in the 1960s did theological and ethical, in contrast to prudential, grounds emerge within the Church for the strategy of accommodation. With the theological analyses of a Jesuit, John Courtney Murray, showing the way, Vatican II taught for the first time that religious freedom is a sacred human right, founded on the requirements of human personality. This means, at a minimum, that everyone must be free to act in accordance with his or her own convictions on religious matters, without coercion by individuals or social groups or other human powers. It also means that the search for religious truth must be carried out in a manner appropriate to the dignity and social nature of the human person: by free inquiry, communication, and dialogue. ${ }^{53}$

Missionary activity was reconceived accordingly: "The church strictly forbids that anyone should be forced to accept the faith, or be induced or enticed by unworthy devices; as it likewise strongly defends the principle that no one should be frightened away from the faith by unjust harassment." ${ }^{54}$

\footnotetext{
52 John T. Noonan, Jr., “Development in Moral Doctrine,” Theological Studies 54 (1993), 667, referring to Thomas Aquinas, Summa Theologiae, II-II, q11, a3.

53 “Dignitatis Humanae,” 7 December 1965, in Vatican Council II: The Basic Sixteen Documents, ed. Austin Flannery, OP (Northport: Costello Publishing, 1996), 551-568.

54 “Ad Gentes Divinitus,” 7 December 1965, in Vatican Council II, 443-499, at 462.
} 
The question for us is about "inducement or enticement by unworthy devices.” Ricci and the Jesuits in China provide us with material for consideration. It is not our intent to repeat the canard of some $16^{\text {th }}$ and $17^{\text {th }}$ century Protestant pamphleteers that the Jesuits took their inspiration from Machiavelli and his maxim that "in the actions of men ... the end justifies the means." 55 Nonetheless, there is a striking resemblance between the Jesuits' strategic use of ideas they believed to be false and Machiavelli's advice to rulers on how religious belief can be used for strategic ends. ("Everything that happens that fosters religious faith, even if [the rulers] privately judge it to be false, they should support and encourage. ${ }^{56}$ ) The Jesuits went to China to convert the population and were prepared to use various dubious tactics to accomplish this goal. Given the theology of the time, perhaps this is not surprising. But, in our estimation, they failed to respect the principle that faith must be freely chosen. To be sure, they avoided coercion, which they knew could not lead to salvation. Between coercion and rational persuasion, however, there is manipulation.

At one end, rational persuasion is deliberation on the merits. It works only with shared concerns and common grounds of reasoning. Short of this ideal is nonrational persuasion, such as the use of rhetoric. This need not be manipulative, although some uses are. Doubt enters with the strategic use of belief and argument, such as attempting to persuade others of the truth of ideas that one believes are false. Manipulation becomes more like coercion when it involves constraining others' choices by controlling their perception of a situation or their understanding of available alternatives. The reason such techniques are employed, of course, is to undermine or block what would have otherwise been chosen.

\section{Accommodation Revisited.}

As we move from thinking about the $17^{\text {th }}$ century to thinking about the $21^{\text {st }}$, our analysis leaves us with two large questions. What conception of religious missionary work is consistent with freedom of conscience? And how shall we think now about the strategy of accommodation, in both religious and secular missionary endeavors?

\footnotetext{
55 This phrase is from the Modern Library edition of Machiavelli's political writings and is an unfortunate mistranslation. See Kenneth Winston, "Moral Opportunism: A Case Study," Integrity and Conscience [NOMOS XL], edited by Ian Shapiro and Robert M. Adams (New York: New York University Press, 1998), 184 n37.

${ }^{56}$ Niccolo Machiavelli, Selected Political Writings, ed. and trans. by David Wootton (Indianapolis: Hackett Publishing Co., 1994), 117.
} 
On the first question, we take note of the missionary vision explicit in contemporary Jesuit documents. For example, the complementary norms to the Constitutions of the Society, the definitive guide to community life, characterize the mission of the Society today ("the service of faith”) in terms of the promotion of justice in society. This encompasses, among other things, protection of the human rights of persons and peoples, including socioeconomic rights, the right to progress, and the right to cultural integrity. These efforts must aim at changing the conditions that sustain an unjust and oppressive social order, especially for the poor. ${ }^{57}$

Documents of the general congregations are often incorporated into the complementary norms and serve as an elaboration of them. Decree Three of the $34^{\text {th }}$ General Congregation of the Society, held in 1995, emphasizes the centrality of working with the poor and working for justice, placing all ministries of the contemporary Society of Jesus - education, theology, and so on-in this broader context. In a very strong statement of this theme, Decree Three says:

"In each of our different apostolates, we must create communities of solidarity in seeking justice. Working together with our colleagues, every Jesuit in his ministry can and should promote justice in one or more of the following ways: (a) direct service and accompaniment of the poor, (b) developing awareness of the demands of justice joined to the social responsibility to achieve it, (c) participating in social mobilization for the creation of a more just social order."58

In other words, missionary work is as much about development as about evangelism. Indeed, it is about evangelism by means of development. It focuses not on recruiting church members through conversion but on serving all members of the kingdom of God, i.e., all of humanity. It is work for this world not (only) the next, and in all societies and cultures where people are in need. This view of the mission of Jesus makes concrete the idea of bringing good news to the poor, freedom to the oppressed, healing to the broken. Its hope is that the work of

\footnotetext{
57 The Constitutions of the Society of Jesus and Their Complementary Norms (Saint Louis: Institute of Jesuit Sources, 1996), Part VII, \#\# 245-247, pp. 271-274.

58 Documents of the Thirty-Fourth General Congregation of the Society of Jesus (Saint Louis: Institute of Jesuit Sources, 1995), Decree Three: “Our Mission and Justice,” \#19, p. 46.
} 
the missionary will be an example of and witness to the attractiveness of Christianity. The goal is conversion in the sense of turning people toward a life defined by the values of peace, justice, and forgiveness, which can happen with or without conversion in the traditional sense of adopting certain dogmas. This gives a new meaning to what is Christian-and important—about this kind of work: establishing and nurturing communities that witness to the possibility of realizing fundamental human values.

As worthy as this work is, however, in our view this new conception of evangelism does not go quite far enough. The saving grace of the mission to China was that, once there, the Jesuits were so impressed with what they saw (so we believe) that they were open to a bit of conversion themselves. Respect for freedom of conscience begins with oneself, and the openness of the converter to conversion is one of its identifying marks. Vatican Council II set the stage for this thought in the decree on religious liberty and the declaration on the relation of the Church to non-Christian religions. In these documents, the Council repudiated the Church's historical advocacy of state established Catholicism and recognized that truth and holiness can be found in all of the great religions, not just Catholicism. It urged respect for religious diversity and dialogue and spoke especially strongly against anti-Semitism.

The Council's emphasis on religious freedom and inter-religious dialogue bore fruit in both theological debate and concrete activities. Analogously to development, however, there are two ways to think about the interaction. One is to see inter-religious dialogue as a means to a fixed end, a way of engaging with other traditions so that Catholic doctrines and practices will come to be accepted as an alternative to other traditions (or as a superior formulation of them). The other is to see inter-religious dialogue as more dynamic, less predetermined, with each tradition enriching the others, perhaps to emerge in a new synthesis or new forms of the original beliefs. The theological move here is the notion that God has engaged in successive revelations, not just once-in Jesus as the fulfillment of the covenant with Israel—but differently in other traditions, in other places, in other terms.

Some individual theologians have made this move, but the Society of Jesus has not. Yet, we believe Ricci can be cited for both interpretations. In his use of early Confucian sources, he argued that the notion of a personal creator God, crucial to Christianity, had roots in Chinese tradition. This illustrates dialogue in the limited sense of trying to understand how the beliefs of others reflect the work of the Christian God. The aim is to educate people to recognize the 
mysteries of God already implicit in their lives. Inculturation of the missionary is required, in this view, because only with thorough and loving attention to the details of the beliefs and practices of others is it possible to see God's presence. In this approach, there is no sense that Christianity itself might be open to question. On the other hand, Ricci's accommodationism may also be seen as a genuine repudiation of fixed and judgmental attitudes, exhibiting openness to new insights and understandings. His warm appreciation of the ancient Confucian texts hints at this posture. In this view, inculturation is required to fully grasp alternative revelations.

Contemporary Jesuits are conflicted about whether dialogue is a means to a fixed end or a commitment to openness and possible transformation. The complementary norms to the Constitutions, following the discussion of mission quoted above, say:

"In this mission, its aim (the service of faith) and its integrating principle (faith directed toward the justice of the Kingdom) are dynamically related to the inculturated proclamation of the Gospel and to dialogue with other religious traditions as integral dimensions of evangelization.”59

Contemporary Jesuit theology and practice are reasonably clear about what "inculturated proclamation of the Gospel” means, and also reasonably clear (though discreet) about their differences with the Vatican on this issue. Inculturation means recognizing that the institutional and liturgical forms and many of the doctrinal formulations of Catholicism developed in the west are not integral to the gospel, and that one can, for example, preach "Jesus with an Asian face."

In this view, Christianity is a "way," analogous to the "ways” of Confucianism, Buddhism, and Hinduism, and can incorporate Asian practice-including, yes, veneration of ancestors-into the liturgy. Both theologians and the Federation of Asian Bishops Conference (FABC) have been clear and creative about the possibility and the importance of developing "a new way of being church in Asia” that is genuinely Asian, not Roman. ${ }^{60}$ On the other hand, the Vatican, specifically Cardinal Ratzinger, now Pope Benedict XVI, apparently disagrees with the

\footnotetext{
59 The Constitutions of the Society of Jesus, Part VII, \#245, section 3, p. 271.

60 See, for example, Peter C. Pham, In Our Own Tongues: Perspectives from Asia on Mission and Inculturation (Maryknoll: Orbis, 2003), and Michael Amaladoss, The Asian Jesus (Maryknoll: Orbis, 2006). See also John Fuellenbach, Church: Community for the Kingdom (Maryknoll: Orbis, 2002).
} 
conclusions of the Asian Bishops Conference on this issue, and continues to claim that church unity requires that the Roman rites, with all their western European trappings, be practiced throughout the world. The FABC appears to be ignoring Ratzinger's pronouncements.

Still, it is not easy to find an unambiguous commitment to open inter-religious dialogue in Jesuit documents. Francis X. Clooney formulates the difficulty by noting that Catholics have two callings and thus need to do two things at once. They need to proclaim the Gospel, and they need to "re-imagine our religious identities in a context of dialog ... We need to keep together the elements [which the Jesuits in China] kept together: accommodation and evangelical zeal, certainty and openness, interreligious learning and Christian mission.”61 The question is whether it is possible to do both. Does the spiritual encounter with others serve Christians in discovering deeper dimensions of their existing faith? Or does the search for spiritual and moral truth mean that they do themselves a disservice if they assume they have nothing to learn from others? In our view, equity is a fundamental requirement. One can criticize if one is open to criticism. One can assess the plausibility and cogency of others' beliefs, if one is ready to assess one's own.

The key is acknowledging that no one occupies an ideal space for warranting beliefs, even those who claim divine authority. When we examine the actual history of allegedly inescapable and immutable principles, we discover that they undergo transformation over time, in response to political and social developments, technological change, and evolving needs. ${ }^{62}$ This does not diminish our commitment to the search for common ground and universal truth. But it means that even when we do the very best we can by way of exercising our moral capacities, we recognize the limits of human understanding and the continuing need to be ready to revise our beliefs, when revision is called for. In a reflective moral life, nothing is immune to examination. We have the most confidence, presumably, in those judgments that are most difficult for us to give up or revise. But that is not to say our convictions are warranted simply because we cannot help believing them; even our most considered judgments are not selfvalidating. Rather, there's simply no alternative to believing what one most strongly believes.

\footnotetext{
${ }^{61}$ Francis X. Clooney, SJ, “A Charism for Dialog: Advice from the Early Jesuit Missionaries in Our World of Religious Pluralism,” Studies in the Spirituality of Jesuits 34:2 (2002), 2 and 35.

${ }^{62}$ Noonan describes changes in Catholic moral teachings on usury, marriage, slavery, and religious freedom in "Development in Moral Doctrine," 662-677. For an extended account on these and other issues, see John T. Noonan, Jr., A Church That Can and Cannot Change (Notre Dame: University of Notre Dame Press, 2005).
} 
(Note Nietzsche's caution, however: “A very popular error: having the courage of one’s convictions. Rather, it is a matter of having the courage for an attack on one's convictions.”)

The challenge is especially acute when professionals cross familiar geographical and cultural boundaries, finding themselves attempting to mediate between settled understandings and alternative ways of life, and is relevant to secular as well as religious missionary work. It is important that moral learning transcend local conditioning. Professionals need to understand the point of view of others and be prepared to give weight to what is sound in alternative perspectives. The interesting, if difficult, question is: Which others should we take seriously? Chad Hansen suggests that sincere confrontation with a rival moral tradition destabilizes our moral confidence when the rival has three features: (1) it is intellectually rich and a product of deep and sustained reflection; (2) it is significantly different in its conceptual structure or theoretical orientation; and (3) it satisfies a threshold condition of plausible rightness, either historically (as the foundation of a major civilization) and/or substantively (generating what one regards as correct moral judgments). If all these conditions are met, one may find the rival tradition sufficiently attractive to induce a re-examination of one's own most basic assumptions. At a certain point, one may begin to engage in the effort to synthesize different truths. ${ }^{63}$

We do not want to underestimate-although equally not overestimate — the difficulty of taking others seriously. We want to resist the impulse to transform partial and perhaps complementary perspectives into irreconcilable standpoints, yet we do not want to deny real differences. It is all too easy to go wrong in either direction, assuming that others are just like us or, alternatively, completely opaque to us. No matter how successful we are in understanding alternative normative orders, there will be cases where we regard a society as admirable, highly cultured, sophisticated, or advanced (whichever term one is inclined to use) and still regard some of its practices as unacceptable, if not repugnant. On other occasions, however, one will be moved toward re-examination of one's own most considered views.

When Ricci translated Christian concepts into Chinese, and showed how it was possible to reconcile the naturalistic ethics of Confucius with a Christian worldview, and especially when

\footnotetext{
${ }^{63}$ Chad Hansen, "The Normative Impact of Comparative Ethics: Human Rights," in Confucian Ethics: A Comparative Study of Self, Autonomy, and Community, edited by Kwong-loi Shun and David B. Wong (Cambridge, Eng.: Cambridge University Press, 2004), 79. For discussion of the issues in these paragraphs, see Kenneth Winston, "What Makes Ethics Practical,” HKS Faculty Research Working Paper RWP08-013 (2008), especially 4248.
} 
he incorporated Chinese veneration of ancestors into Christian practice, he may have seen himself as acting instrumentally, or he may have been entering into a genuine dialogue in which he was willing to learn as well as teach. This possibility clearly horrified some at the time, but we see it as a compelling model — using the light of natural reason, receptive to being changed by the new culture as well as changing it. It is interesting to us that Ricci may have anticipated this stance and that some contemporary Jesuits embrace it, in practice if not quite yet in theory.

This stance embodies an ethically grounded strategy of accommodation. As professionals engage today in secular forms of missionary work - whether it is promoting the rule of law or free-market capitalism or, in our case, "best practices" of good government-we need to be constantly aware that our deepest commitments are historically situated and politically charged. In the encounter with people who are differently situated, we are challenged to engage in a kind of double reflection: to grasp what something could mean to others, especially when at variance with our own understanding, and to contemplate the contestability of our own worldview. These are difficult skills to cultivate, yet they seem to us indispensable to genuine engagement with other peoples.

That was our most enduring thought as we contemplated the gravesites in the Zhalan cemetery in Beijing. ${ }^{64}$

\footnotetext{
${ }^{64}$ On missionary efforts subsequent to the normalization of U.S.-China relations in the early 1970s, encompassing not only religious but academic and development missions, see Richard Madsen, China and the American Dream: A Moral Inquiry (Berkeley: University of California Press, 1995), especially chapter 6: "Missionaries of the American Dream: Putting the Liberal Myth into Practice.”
} 